JournEEL

E-ISSN: - Vol. 1 No. 1, June 2019, Page. 45-51

\title{
The Implementation of Religious and Moral Education at Kindergarten
}

\author{
Agustinus Ngadiman \\ STKIP PGRI Sidoarjo, Email: agustinus.ngadiman@ gmail.com \\ Fithriyah Putri Perdana \\ STKIP PGRI Sidoarjo, Email: fithriyahpp@gmail.com
}

\begin{abstract}
Religious and moral education from an early age so needs to be invested for the child, so that in the future they will have a strong and deep understanding of the norms and teachings of Islam. Age children early childhood and kindergarten (TK) is a time to play, so education is implemented particularly religious education should be designed properly by the teacher so that the education process into an active and fun activities. Kindergarten (TK) Darma Wanita Sekardangan, Sidoarjo is one of the educational institutions that provide education for early childhood, with one lesson material is a moral and religious education. Moral education is one of the materials is very important because in load values, morals and religion, so this will be a guide for students in later life. The research method used is descriptive qualitative research to describe in detail the subjects and issues to be studied. The findings in this study is the cultivation of religious values and morals for children Kindergarten revolves around the activities of daily life. In particular cultivation of religious values with laying the foundations of the faith, personality or character that is commendable and devotional practices, in accordance with the child's ability is implemented. As one of the early childhood education institutions, in conducting the study, have several models of delivery Edutainment, habituation and uswah hasanah as a reference implementation of teaching and learning.
\end{abstract}

Keywords: Values of Religion, Moral, Habituation, Edutainment, Modeling (Uswah Hasanah).

\section{INTRODUCTION}

Education is a conscious and deliberate effort in order to transfer knowledge and values of adults to students. Educational process taking place will greatly affect the outcome including the learning model used. In the daily reality of the problems faced is how the educator can do their job properly, because lately a lot of students are still lacking in understanding Islam. For a while it was known that an activelearning approach (active learning strategy) is as an alternative to meet the challenges of these problems. Starting from these ideas, the writer is interested in conducting this research.

Religious and moral education from an early age is really important to be invested for the children, so that in the future they will have a strong and deep 
understanding of the norms and teachings of Islam. Child age, early childhood and kindergarten (TK) is a time to play, so education which implemented particularly religious education should be designed properly by the teacher to the educational process into an active and fun activities. Bustami (2007) says that the Islamic Religious education means systematic and pragmatic in helping students to live in accordance with Islamic teachings.

Meanwhile Lauwerys (2018) defines the Islamic Education is a conscious effort to transfer the experience of the older generation of knowledge, expertise and skills to the younger generation so that later they will became Muslim man, devoted to Allah SWT. Virtuous and have noble personality who understand, appreciate and practice the teachings of Islam in their lives. On the other hand, Ahmad Tafsir (2005) gives the sense that Islamic education is the guidance given by someone to someone so that he growns up optimally in accordance with the teachings of Islam. When abbreviated, Islamic religious education is guidance to a person in order to become the best Muslims.

This education will be a good result just like a building, which will be a solid foundation underlying dependent, so if it is applied in education, early education is very important as a foundation for their education to the next level. Early childhood education is one form of organization of education that focuses on laying the foundation toward 5 growth and development, namely: the development of moral and religion physical development (coordination of fine and gross motor), intelligence/ cognitive (thinking, creativity), socio-emotional (attitudes and emotions) language and communication, according to the uniqueness and stages of development of the appropriate age group traversed by younger children as stipulated in the Ministerial Regulation No. 58 of 2009.

Kindergarten (TK) Darma Wanita is one of the educational institutions that provide education for early childhood, with one lesson material is a moral and religious education. Moral education is one of the materials which is very important because it is full of values, morals and religion, so this will be a guide for students in later life.Kindergarten Education (TK) is one form of education foundation before they go to school to a higher level, so that what is gained during their child's education here will proceed to secondary school. 
The problem of this study are how is the implementation of religious and moral education in kindergarten TK Darma Wanita? And what are the methodology used to implemented the religious and moral educatio in kindergarten?. Moreover, the objectives of the study are to know the the implementation of religious and moral education in kindergarten TK Darma Wanita and to know the methodology used to implemented the religious and moral educatio in kindergarten. As in this study the writer used a qualitative approach which does not use the calculation but using the phrase description Sugiyono (2007: 283).

\section{RESEARCH METHOD}

The researcher used descriptive qualitative for the research dessign. All the results of the data, described descriptively. According to (James Dean Brown, Rodgers, 2003), they stated that qualitative research approach is typically the label for nonnumerical research. The subject of this study were the students of the first class at kindergarten (TK) DarmaWanita and the teacher.As Schwandt, Thomas A (2015) stated that field notes are intended to be read by the researcher as evidence to produce meaning and an understanding of the culture, social situation, or phenomenon being studied.The data of this study were gotten from the result of observation fieldnote in observing children's moral after being taught religious education as the answer of the first statement. The researcher observed the implementation of religious education for children at kindergarten. Moreover, the researcher took a documentation from the children report as the answer of the second statement.

Furthermore, the source of the data is the implementation of religious and moral education in the first grade of kindergarten in Sidoarjo. This activity held everyday in a first week of new semesterand followed by students of kindergaten in Sidoarjo and the teacher. To analyze the data, the researcher identify the implementation teaching learning process of religious and moral education. After that, to answer the first statement, the researcher sort the steps of the teaching learning process, drew the conclussion and all the activity are supported by the result of the report documentation as the answer of the second statement. 


\section{FINDINGS}

The researcher observed in the first week of second semester. The researcher found that students always said salam "assalamu'alaikum" when they entered the class. They took their bag on the chair and went outside to play with their friends before the bell rang. When the bell rang, students immadiately made a line neatly in front of the class. After that, the teacher guide the students to sing shalawat nariyah,pray Al-fatihah, Al-ikhlas, An-nas and Al-falaq. Next,they entered the class. The teacher asked the student's condition and they always answered "fine" together.

The teacher asked the students to pray, mention the muslim principle and mention the faith of muslim principle before they started to study. All students looked remember that. They looed like anthusias because After they done praying, the teacher asked them to take their coloring magazine in their own locker orderly and then they started to coloring it. The teacher always asked the students to let their another friends to borrow their color pencil. They shared their color pencil to the friends who did not bring it.

Oher than coloring activity, the teacher also asked the students to practice to salat, gymnastics, traditional dancing, and practice to play rebbana. The teacher always enhanced moral and religious education to all the activity done by the students. For the example, the teacher asked them to share, stay orderly in every activity, tolerated, and asked them to be polite to the teacher and older person.

After the main activity done, the students took a rest together. They ate their meal orderly. As usual, they prayed before they did anything. After that they are allowed to play in a play ground for 15 minutes. After 15 minutes, the bell rang and they had to entered the class. The teacher reminded the students about all the activity done that day. Before they go home, the teacher always made some question such as how to pray salat, mention the muslim principle, and so on. Student who can answer the teacher's question could go home first.

Moreover, the result of documentation shows that there are 2 students of 20 that still can not remember the muslim principle. 4 students still can not pray Al-Fatihah and Al-Falaq. 18 students still can not remember how to pray in shalat. In the other hand, all the students already know what they should do and what they should not do. They also can mention God's creature. 


\section{DISCUSSION}

Based on the result of the observation, the researcher could find a good interaction when the students played in the play ground with their friends. Also, praying before doing anything is a good habituation. Those two things are good for children. As Marry (2018) said that Teaching children to pray is a vital part of introducing them to God and reinforcing their relationship with God. Our Lord gave us prayer so we could communicate with him directly, and getting children comfortable with prayer helps them to understand that God is always close and accessible.

The implementation of religious and moral education for childen in a school with a habitual way will make a good output. It is also an effort otherwise parents nowadays are busy with their career. In early childhood education institutions, moral and religious values are instilled through habituation. One of the behaviors instilled in early childhood is pray before and after doing activities. In daily activities.

The teacher or many kindergarten educators who teach certain prayers that are sufficientlong every time you want to do certain activities in class, like prayer before study, before eating, after eating and other do'a that are still of a nature memorize only and do not emphasize the meaning or values contained in reading the prayer. Even in some kindergartens, especially kindergartens under the foundation on behalf of Muslims, many educators teach do'a-do'a by using Arabic that is not included in the meaning, so that the child only memorized what was said without knowing what he meant. Some prayer these are routinely accustomed to children by the way children are asked to say the prayer in a loud voice.

Seeing moral learning and religious values through reading prayers it appears that children cannot necessarily grasp the meaning or value of the prayer is pronounced, because the language used is Arabic which has not been understood by children. Besides that, the learning process is applied sometimes less applicable because when teaching prayer, children are asked to say the do'a-doa was loud in class.

In accordance with Kohlberg's stage of moral development, children are included at the stage of pre-conventional moral development, where children's behavior is controlled by the physical consequences of actions which usually appear in the form of gifts and punishments. Thus the cultivation of moral and religious values at this time also needs to be cultivated by giving various forms of "lure" or gifts when the child does 
something positive and provide certain threats or penalties that are educational in nature if the child carries out inappropriate behavior.

Regarding the formation of moral behavior, one of the issues raised in the findings of the study conducted by the Institute of Education Sciences on moral behavior in students is represented by the "child's requirement of a viablesocial model" because the teachers propose a theoretical model regarding how the student should be and/or what thestudent should become without being consonant to his own needs and those required by contemporary society (Badea, D.\& colab., 2011). In promoting moral behavior, it is necessary to permanently relate both to us and equally to others, as also stated by V. Morar "the ethics core triangle is composed of ME, YOU and HIM". (Morar, V., 2013)

Moral conscience refers to a set of cognitive structures and intellectual principles, backed by affectivemotivational states, that enable us to differentiate between right and wrong and guarantee the correct use, in relation to self and others, of the freedom of action of the human subject (Stan, C., 2001).

The description of moral education and religious values competencies, as outlined by the early childhood education curriculum shows that moral education and religious values are instilled not only in religious worship activities that are routine but through widely in various children's activities in daily life, including how to cultivate affection with others, responsibility, courtesy, cleanliness and neatness and order in the rules. Thus, there are many ways, times and activities that can be used to instill moral and religious values in children's daily activities, most of which are used to interact with friends and the surrounding environment.

\section{CONCLUSSION}

Establishing religious values and morals for children at Kindergarten revolves around the activities of daily life. Specifically establishing religious values to children of kindergarten is laying the foundations of the faith, personality or character commendable and habits of worship according to their ability.

As one of the early childhood education, TK Putra Harapan Nalumsari also pursues the implementation of educational activities for children in the neighborhood. In 
conducting the study, Kindergarten (TK) Darma Wanita has some methods as the reference of implementation in the teaching and learning.

Among them is the habituation learning model and exemplary method (uswah hasanah) used in carrying out the teaching and learning activities at Kindergarten (TK)Darma Wanita especially an application method of habituation to the values of worship.

\section{REFERENCES.}

Badea, D., \& colab., (2011). Responsabilitatea profesorului în formarea moral-afectivă a tinerilor. Bucureşti: Institutul de Ştiinţe ale Educaţiei

Khir M.S, Bustami. (2007). Islamic Studies Within Islam: definition,Approaches and Challenges of Modernity. London

Mary. (2018). 6 Simple Tips for Teaching Children to Pray. London. ThoughtCo.

Morar, V., Juc, V. (coord.). (2013). Dialogul Civilizaţiilor: etică, educaţie, libertate și responsabilitate într-o lume în schimbare, Chișinău.

Tafsir, Ahmad. (2005). Ilmu Pendidikan Dalam Persfektif Islam. Bandung: Remaja Rosdakarya

Joseph A. Lauwerys (2018). Education. Encyclopaedia Britannica. Encyclopaedia Britannica inc. https://www.britannica.com/topic/education/Aims-andpurposes-of-Muslim-education

James Dean Brown, Rodgers. (2003). Doing Second Language Research. New York: Oxford University Press.

Sugiyonno. (2014). Metode penelitian pendidikan: pendekatan kuantitatif, kualitatif dan $R \& D$. Bandung, Alfabeta.

Stan, C. (2001). Teoria educaţiei. Actualitate şi perspective. Cluj-Napoca: Ed. Presa Universitară Clujeană.

Schwandt, Thomas A. (2015).The SAGE Dictionary of Qualitative Inquiry. 4th edition. Thousand Oaks, CA: SAGE. 